\title{
Biological treatment of produced water in a sequencing batch reactor by a consortium of isolated halophilic microorganisms
}

\begin{abstract}
Produced water or oilfield wastewater is the largest volume of a waste stream associated with oil and gas production. The aim of this study was to investigate the biological pretreatment of synthetic and real produced water in a sequencing batch reactor (SBR) to remove hydrocarbon compounds. The SBR was inoculated with isolated tropical halophilic microorganisms capable of degrading crude oil. A total sequence of $24 \mathrm{~h}$ (60 min filling phase; $21 \mathrm{~h}$ aeration; 60 min settling and 60 min decant phase) was employed and studied. Synthetic produced water was treated with various organic loading rates (OLR) $(0.9 \mathrm{~kg}$ COD mī 3 dī 1, $1.8 \mathrm{~kg}$ COD mī 3 dī 1 and 3.6 kg COD mī 3 dī 1) and different total dissolved solids (TDS) concentration (35,000 mg Lī 1, 100,000 mg Lī 1, 150,000 mg Lī 1, 200,000 mg Lì 1 and 250,000 mg Lì 1). It was found that with an OLR of $0.9 \mathrm{~kg} \mathrm{COD} \mathrm{mī} 3$ dī 1 and 1.8 $\mathrm{kg}$ COD $\mathrm{mi} 3 \mathrm{~d} \overline{1} 1$, average oil and grease $(\mathrm{O} \& \mathrm{G})$ concentrations in the effluent were $7 \mathrm{mg}$ Lì 1 and $12 \mathrm{mg}$ Lì 1, respectively. At TDS concentration of 35,000 mg Lī 1 and at an OLR of $1.8 \mathrm{~kg}$ COD mī 3dī 1, COD and O\&G removal efficiencies were more than 90\%. However, with increase in salt content to $250,000 \mathrm{mg} \mathrm{Li} 1, \mathrm{COD}$ and O\&G removal efficiencies decreased to $74 \%$ and $63 \%$, respectively. The results of biological treatment of real produced water showed that the removal rates of the main pollutants of wastewater, such as COD, TOC and O\&G, were above $81 \%, 83 \%$, and $85 \%$, respectively.
\end{abstract}

Keyword: Oilfield brine; Oilfield wastewater; Produced water; Sequencing batch reactor; Tropical halophilic microorganisms 